\title{
THE INFLUENCE OF THE ETHNIC AND CONFESSIONAL PARTICULARITIES ON THE INFANT MORTALITY AT THE LOCAL LEVEL (IAȘI COUNTY)
}

\author{
Simona Andreea URSACHE (DUMITRIU) * \\ „Alexandru Ioan Cuza” University of Iaşi, Faculty of Geography and Geology, Department of Geography, Iași, Romania, \\ e-mail: simona93u@yahoo.com \\ Ionel MUNTELE \\ „,Alexandru Ioan Cuza” University of Iaşi, Faculty of Geography and Geology, Department of Geography, Iași, Romania, \\ e-mail: imuntele@yahoo.fr
}

Citation: Ursache, S.A., \& Muntele, I. (2020). The Influence of the Ethnic and Confessional Particularities on the Infant Mortality at the Local Level (Iaşi County). Analele Universităţii din Oradea, Seria Geografie, 30(2), 122-130. https://doi.org/10.30892/auog.302101-845

\begin{abstract}
The world is today a healthier and safer place than ever, and children have the chance to become responsible adults and to enjoy their lives. Romania has made unquestionable progress, especially in the last two decades, with infant mortality rates increasingly approaching the European average. However, our country still occupies leading places across the European continent on child deaths, with children remaining in our society, the most vulnerable social category. Strong territorial and social disparities mark this positive development. In our study we intend to identify the particularities (ethnic and confessional) that influence, in some cases, child mortality in Iași county (four types of communes with distinct ethnic and confessional). Whereas a clearing-up is taking place in Iași county between vulnerable socio-economic communities and those with higher levels of development. The results of the study show a stronger correlation between the ethnic factor and the level of infant mortality as opposed to the confessional factor, closely linked to the incidence of educational, economic or demographic factors.
\end{abstract}

Key words: infant mortality, ethnic component, confessional component, living standard

$* \quad * \quad * \quad * \quad * \quad *$

\section{INTRODUCTION}

Child mortality is one of the most important demographic indicators, expressed in terms of the number of child deaths in the first year of life, and is calculated by reporting deaths under one year of age in 1000 live births in the same year (Reidpath, 2003; Rotariu, 2009). Roland Pressat believes that the infant deaths can be divided into in two categories: endogenous deaths (usually 
heritable, congenital malformations or traumatism caused by birth) and exogenous deaths (caused by external risks: infectious, respiratory, food, accident) (Pressat, 1974; Trebici, 1975). In the literature, intense knowledge of infant mortality by age subgroups is very important, especially in the first week of life (0-6 days - early morality), in the first month (0-29 days - neonatal mortality) or up to 11 months (1-11 months post-neonatal mortality) (Dumitrache, 2004).

Both at global and local level this indicator surfing social and economic trends in society, the level of development, the standard of living or the efficiency of the health system. There are high levels of child mortality worldwide in sub-Saharan Africa, but overall progress is being made in reducing child deaths also in Latin American, North Africa or Asia (Onambele et al., 2019; Storeygard et al., 2008).

At European level, the decline in infant mortality which being in the first decades of the nineteenth century, in special in mercantilistic state, economically developed, with a well-organized bureaucracy (state controlled Protestant Church) (Corsini and Viazzo, 1993).

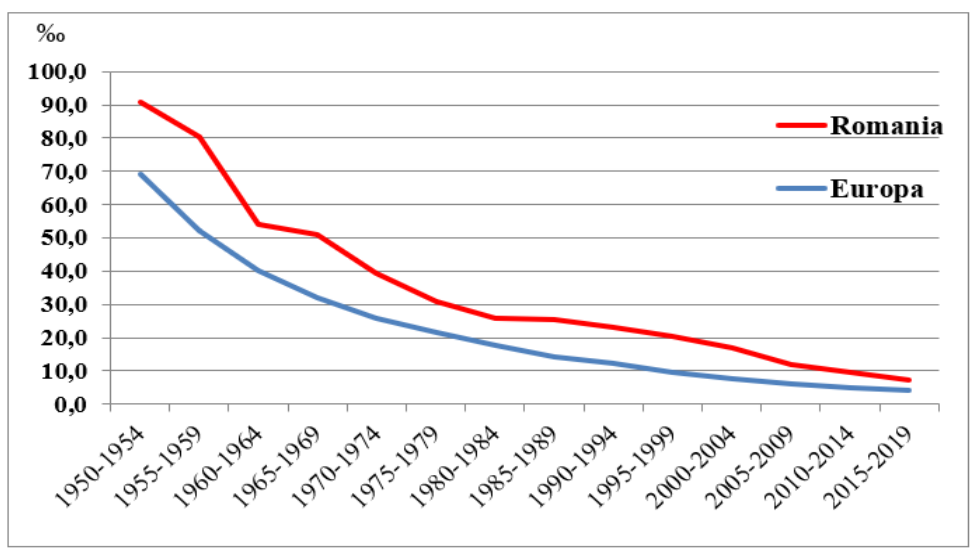

Figure 1. Comparative evolution of infant mortality in Romania and Europe

Data source: Bardet and Dupâquier, 1999; World Population Data Sheet, 1995-2019 series, Population Reference Bureau, Washington

Differences between European countries have been steadily decreasing over the $20^{\text {th }}$ century, not only in terms of recent infant mortality but also in terms of decline in fertility or the modicing of matrimonial property (Bardet and Dupaquier, 1999). In this context, Romania, despite the delay caused by the lower level of economic and social development, does not ignore it, and is part of the same general trends at continental level (figure 1). If by 2000 the difference between Romania's average values and the European average values was still considerable, during the last two decades there has been a significant closeness of convergence at continental level with the above mentioned authors.

In present, higher values are noted by the former communist countries (Eastern Europe), but also the Balkan countries that suffered as a result of the military conflicts (Albania, Macedonia, Serbia). The Nordic countries are considered to be the benchmark for health policies with very low values of the indicator analyzed. Within the European Union, the leading place is occupied by our country, even though there has been a constant decrease in child mortality rates in recent years.

At national level infant mortality in 1990 was $26.9 \%$ and by 2007 it had fallen to $12 \%$ o (Kurkó, 2010), in the context of the transition period, the main drivers being the accessibility of abortion, contraception and family planning, which morning the risk of the unwanted child. However, the North-East region is the region with the highest level of fertility in Romania (Jemna, 2015). The regional city with complex functions, Iaşi, (after the 1992 census, it ranks third in the urban hierarchy- after Bucharest and Constanta; in 2002 - the second metropolis of the country) is 
characterized by the highest birth values of all regions of the country, with remarkable natalist behavioris (Istrate, 2008).

Infant mortality is on of the most widely used indicators to assess population health status and at national scale registred an important descendant trend (Burlea, 2012). According to some researchers, child mortality depends on many risk factors: social status and age of mother, gestational age, etc (Waldhoer et al., 2008).

Gabriela Alexandrescu, Executive President Save The Children Romania, believes that the child mortality rate is a good criterion to see the enormous distance between Romania and the more developed countries in the European Union.

\section{METODOLOGY}

The research was based on the data provided by the national Institute of Statistics and the report of 2011, which were further elaborated and corroborated by field surveys. We also used subjective methods in the form of interviews (with mayors, secretaries or social workers). The whole scientific approach was accompanied by statistical analyzes, the most important being the analysis in main components which indicated to us the factors that directly influence infant mortality.

In our research, we have tried to capture a possible influence of ethnic and confessional particularities in the dynamics of the analyzed indicator.

Following the analysis of infant mortality (2001-2017) at national level (in order to highlight trends in child mortality dynamics at Iași county level), we selected at a local level four communes with distinctive characteristics: Lungani, the municipality with the highest share of the roma community in the county, Ruginoasa, a commune with a high degree of accessibility and an interstitional position between the cities of Targu Frumos and Pascani, Mircesti, with a large share of the Catholic community and the Periurban Common Miroslava, who has experienced one of the most spectacular developments at national level in recent years (figure 2).

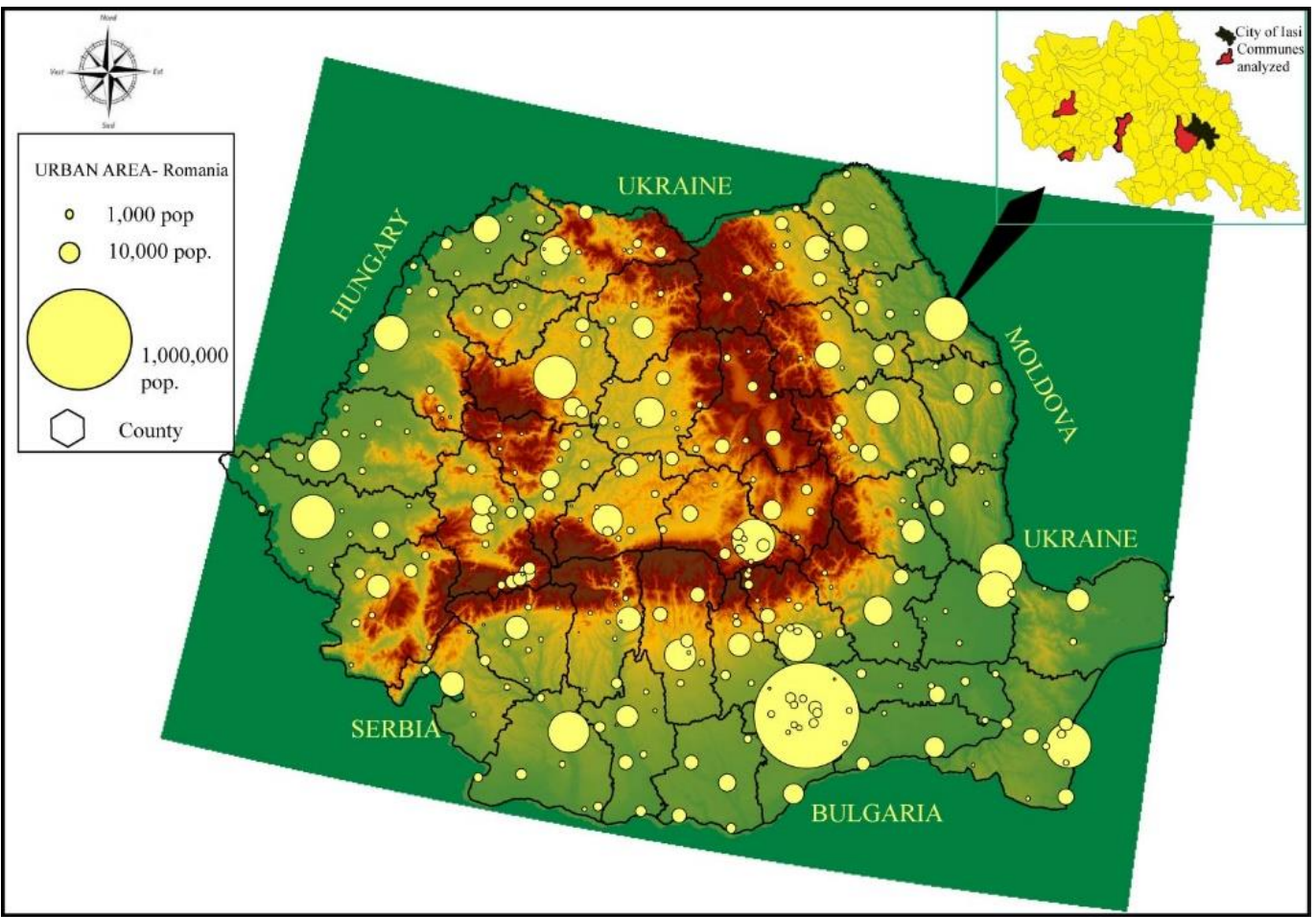

Figure 2. Study area: Iași county 
The Presentation of Hypotheses:

H1: Even if our country has seen a significant decrease in child mortality in recent years, at local level there are high child mortality rates, which influence the dynamics of the indicator analyzed at county level.

H2: A number of factors directly influence the dynamics of child mortality in Iaşi county, which is why the decline in values is related to both the increase in living standards and access to quality medical services, as well as health, education and integration policies that reduce these disparities.

\section{RESULTS}

During the period analyzed, the Iași county was noticed at national level by a significant decrease in child mortality, reaching low values in the period 2013-2017, similar to the Cluj or Timisoara counties. The lowest values are recorded in the Iași municipality, recognized at national level as a university and medical center with a reputation, with differences between urban and rural areas remaining significant. In this context we considered it necessary to carry out field analysis at local level to confirm or rule out the assumption that infant mortality is higher where the proportion of the Roma population or population with a certain confessional membership has high or even very high infant mortality values (figure 3).

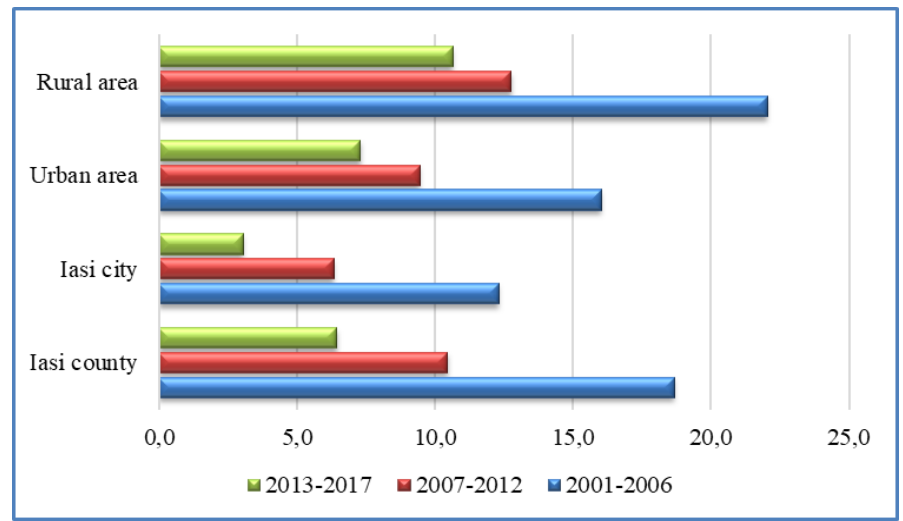

Figure 3. The dynamics of infant mortality in Iaşi county in 2001-2017 Data source: National Institute of Statistics 2001-2017, Bucharest

Lungani, the poorest commune in EU, it is one of the communes with the most infant deaths and implicitly a very high infant mortality value compared to the other communes in the county. At the same time, it is the commune with the most significant share of the Roma population, this aspect directly influencing the analyzed indicator. The birth rate decreases from $26.99 \%$ in the period 2001 2006 to $21.84 \%$ in $2013-2017$, even though the birth rate remains very high compared to the county average or to the other compared municipalities. Following the field investigation conducted at the town hall and following the discussions with the chief secretary, with the personnel from the social assistance and the registry, it is noted that most of the infant deaths are among the Roma population, the main causes of death being pneumonia interstitial and bronchopneumonia, very serious respiratory disorders, encephalopathies and accidents caused by aspiration of gastric contents (one case of ingestion of faces by slipping into the septic tank). This commune is a typical example of correlating the values of infant mortality with the ethnic component, in the case of the Roma minority, the most frequent being the problem of the high illiteracy rate, the lack of a stable job, a very low standard of living and an endemic poverty, the phenomenon of the unwanted child or the inadequate care of the baby due to too much responsibility pressing on the shoulders of large families or even leaving the babies in the care of younger siblings frequently causing accidents or even deaths 
(figure 4). There are also a significant number of social workers in this commune. The rate of illiteracy is declining strongly influenced by the fact that many families live only on the allowance of children, an income they receive only if the children attend a school. From the point of view of proximity the commune is about $45 \mathrm{~km}$ from the city of Iași, an urban center with the best health system and the highest maternity in Moldova and about $15 \mathrm{~km}$ from Târgu-Frumos, an urban center that provides medical services. We can therefore say that the Roma minority influences this indicator, and the development of special States dedicated to them seems the only solution. Even if the integration of the Roma population was raised before the accession to the European Community, the process is long-standing and difficult, with ethnic discrimination still present in European Romania, most likely favored by the lack of involvement of the Roma.

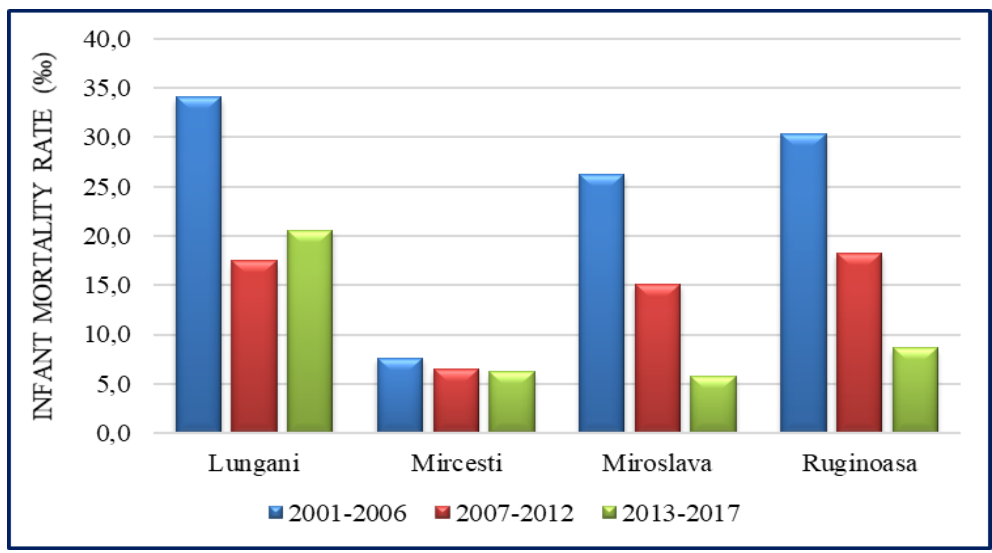

Figure 4. Infant mortality in the analyzed communes, between 2001-2017 Data source: National Institute of Statistics 2001-2017, Bucharest

Investing in their education, ensuring adequate technical-public infrastructure (access to the water network, sewerage, gas), creating jobs, accessing medical services and information (many of the roma women presenting to the doctor even on labor day because the addressability to the doctor is directly influenced by the income), it should be a priority for the local authorities. From a confessional point of view, we chose to compare with Lungani commune, Mircești communes with a Romanian population, homogeneous and predominantly Catholic and Ruginoasa commune, with an exclusively Romanian population and of orthodox religion.

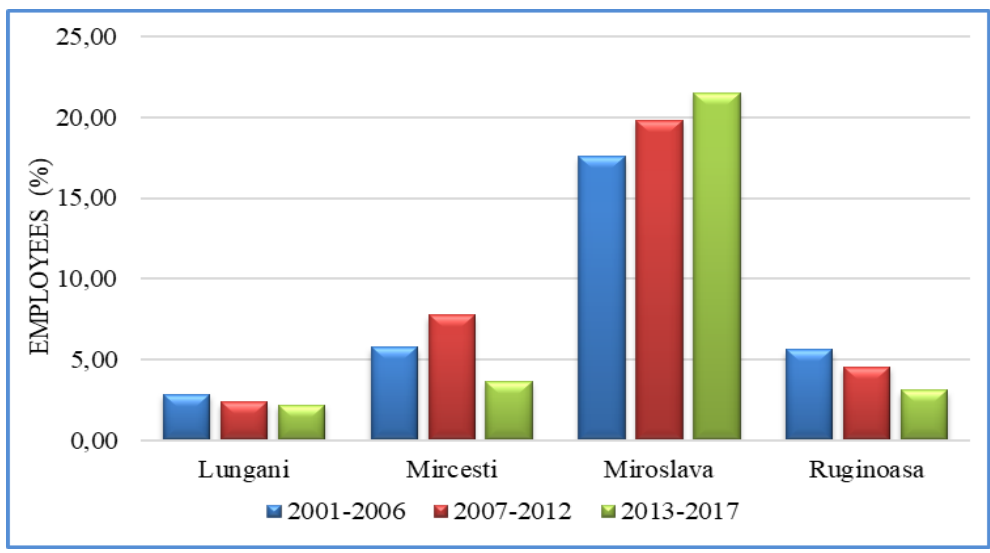

Figure 5. Evolution of the share of the employed population (\%) in 2001-2017 Data source: National Institute of Statistics 2001-2017, Bucharest 
With a peripheral position, on the border with Neamț county, on the right bank of Siret, about $75 \mathrm{~km}$ from Iași, Mircești commune registered one of the lowest values of infant mortality in the county, from 2001 to $2006,17.6 \%$, a value that drops to $6.3 \%$ in the period 2013-2017. A worrying decrease is also recorded in the case of the share of employees that almost halves during the reference period $5.77 \%$ in 2001-2006, an increase in $2007-2012-7.74 \%, 3.62 \%$ in $2013-2017$ ) (figure 5). Following the field investigation we found that in the case of the Catholic population, the migration of the active population is the main problem, the mayor of the commune declaring that about $30 \%$ of the commune's population is abroad.

According to him, the Catholic population was much more receptive than the Romanian population, after 1990 because the young people, helped by relatives or by the Catholic communities from other countries, left with job security that allowed them to later support their families left in the country. This aspect can be observed most easily for example by the material condition of the population of the $100 \%$ Catholic village of Iugani, in comparison with Mircești, in which the orthodox population is predominant. This aspect can be observed during the Siret valley, where the Catholic population is the majority. Recall that the number of social workers increased from about 40 in the period 2001-2006 to 100 in 2013-2017 and the main causes of infant deaths are congenital malformations or pneumonia. An essential aspect is the fact that over time the communal medical services have been greatly modernized, with 3 medical offices in Mirești, a working point of the Medical Foundation Speranţa Barticești, Emergency Center and Permanence Center (operating in the interval $15: 00-8: 00$ ).

Even if the Catholic communities are conservative, prohibiting abortion or contraception, the migration of the fertile population is reflected in the low birthrate and the low infant mortality rate.

Ruginoasa Commune, with a predominantly Romanian, Orthodox population, is also noted for low birth rates, with much higher values of infant mortality $(30.3 \%$ in $2001-2006,18.3 \%$ in 2007-2012 and 8.6\% in 2013-2017) than in Mircești commune. The standard of living is low, the share of employees decreasing from 5.62\% in 2001-2006 to 3.10\% in 2013-2017.

Following the field investigation we found out that in the Ruginoasa the employees are predominantly employees of the companies Delpfi Diesel Systems, one of the most important in the county of Iași, provider of advanced propulsion solutions for the car manufacturers, Avicola, a company specialized in poultry farming based in Târgu-Frumos or Lear Corporation based in Lețcani, factory of car seats, these also ensuring transportation from the free home (the shuttle thus represents the only chance to a better paid job, the interstitial position between the cities of Easter and Târgu-Frumos facilitating this appearance). However, migration of the young population remains a problem. Juvenile delinquency is also a problem reported by local authorities, which is becoming increasingly worrying. The number of social workers in the period 2001-2006 was around 170, decreasing in the period 2013-2017 to 120, but at present the number is increasing. From the point of view of accessibility to the medical services, the commune is privileged by the location in the proximity of two urban centers quite devolved from this point of view, $12 \mathrm{~km}$ from Pașcani, $15 \mathrm{~km}$ from Târgu-Frumos and about 60 from the city of Iași. In the commune work four doctors.

Miroslava commune is a peri-urban commune in Iași County, and since 2004 it is also part of the metropolitan area. It is one of the most successful joint ventures in Romania, after joining the European Union, with impressive development. In 2015 and 2016, the commune was declared the richest in the country in terms of income, paradoxically the pole of wealth but also of poverty being in Iași county. One of the main factors that generated revenue growth in Miroslava was the fact that many companies in Iași and not only moved their administrative and financial headquarters here. During the analyzed period, officially, the commune doubled its total population (from 7550 to about 14838), but unofficially the population seems to be greatly underestimated. The share of employees is very high compared to the other communes analyzed, $21.51 \%$ for the period 2013-2017 and is growing. However, the birth rate does not decrease very much, from $15.12 \%$ in 2001-2006 to $13.91 \%$. As it is natural in a community where there are jobs and a high standard of living that brings well-being, migration is lower. 
As I mentioned above, in order to complete the statistical analysis and the survey on the field, we have also carried out an analysis in the main components, taking into account the abovementioned socio-demographic indicators.

As we can see in the figure below the factors that best correlate with infant mortality are birth rate, share of the Roma population, share of the number of unemployed looking for the first job, share of the population employed in health and social assistance, the share of employees and of population with higher education (figure 6).

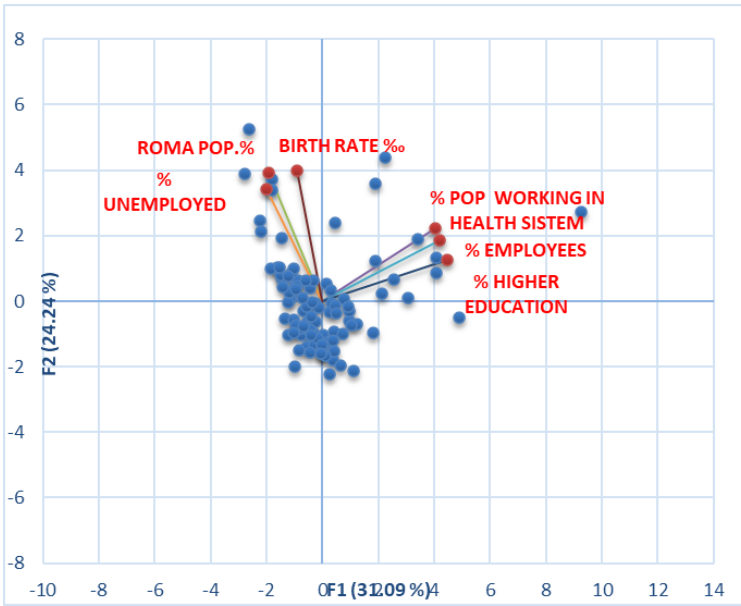

Figure 6. Analysis in main components - the contribution of the factors

In the case of the municipality of Iași and of the peri-urban communes (Rediu, Ciurea, Miroslava) or of the cities of Harlau, Târgu Frumos or Pascani, child mortality seems to be influence by the population in health and social care, by the proportion of the population with higher education and by the share of the employed. Settlements with high accessibility to primary educational services are located in favor of the system of communication routes or the big cities, and are usually localities that have known after 1990 the effects of periurbanization of the socio-professional structure: Miroslava, Tomesti, the Valley of the wolf, Barnova in the Metropolitan area of Iaşi. In the case of Lungani we can also signal the existence of a highly low-qualified educational stock in the adult population, which is why we can believe that the propensity of a community to education is inherited behavior, with both negative and positive states tending to perpetuate (Tudora and Muntele, 2012).

Tabel 1. The Pearson correlation matrix

\begin{tabular}{|c|c|c|c|c|c|c|c|c|c|}
\hline \multicolumn{10}{|l|}{ Correlation matrix (Pearson $(n))$ : } \\
\hline Variables & $\begin{array}{r}\text { INFANT } \\
\text { MORT } \\
\text { ALITY }\end{array}$ & $\begin{array}{c}\text { BIRTH_ } \\
\text { RATE }\end{array}$ & $\begin{array}{l}\text { POP_WORKING_ } \\
\text { HEALTH_SISTEM }\end{array}$ & $\begin{array}{c}\text { ACTIVE } \\
\text { POP }\end{array}$ & $\begin{array}{l}\text { EMPLO } \\
\text { YEES }\end{array}$ & $\begin{array}{l}\text { UNEMP } \\
\text { LOYED }\end{array}$ & $\begin{array}{l}\text { POP_WITHOUT } \\
\text { _EDUCATION }\end{array}$ & $\begin{array}{c}\text { POP_HIGHE } \\
\text { R_EDUCATI } \\
\text { ON }\end{array}$ & RROMA_POP \\
\hline INFANT_MORTALITY (2007- & 1 & 0,1418 & $-0,2809$ & 0,0081 & $-0,2196$ & 0,1896 & 0,0702 & $-0,2013$ & 0,0592 \\
\hline BIRTH_RATE (2007_2016) & 0,1418 & 1 & $-0,0891$ & $-0,3781$ & $-0,0633$ & 0,3882 & 0,3073 & $-0,1577$ & 0,4229 \\
\hline $\begin{array}{l}\text { POP_WORKING_HEALTH_SI } \\
\text { STEM }(\%-2011)\end{array}$ & $-0,2809$ & $-0,0891$ & 1 & $-0,2272$ & 0,6569 & $-0,0823$ & $-0,0991$ & 0,7587 & 0,1158 \\
\hline ACTIVE_POP $(\%-2011)$ & 0,0081 & $-0,3781$ & $-0,2272$ & 1 & $-0,2414$ & $-0,2621$ & $-0,1299$ & $-0,0654$ & $-0,2368$ \\
\hline EMPLOYEES (\%-2011) & $-0,2196$ & $-0,0633$ & 0,6569 & $-0,2414$ & 1 & $-0,1316$ & $-0,2527$ & 0,7582 & 0,0273 \\
\hline UNEMPLOYED (\%-2011) & 0,1896 & 0,3882 & $-0,0823$ & $-0,2621$ & $-0,1316$ & 1 & 0,2497 & $-0,1564$ & 0,3856 \\
\hline $\begin{array}{l}\text { POP_WITHOUT_EDUCATIO } \\
\mathrm{N}(\%-2011)\end{array}$ & 0,0702 & 0,3073 & $-0,0991$ & $-0,1299$ & $-0,2527$ & 0,2497 & 1 & $-0,3112$ & 0,2355 \\
\hline $\begin{array}{l}\text { POP_HIGHER_EDUCATION } \\
(\%-2011)\end{array}$ & $-0,2013$ & $-0,1577$ & 0,7587 & $-0,0654$ & 0,7582 & $-0,1564$ & $-0,3112$ & 1 & $-0,0054$ \\
\hline RROMA_POP (\%-2002-2011) & 0,0592 & 0,4229 & 0,1158 & $-0,2368$ & 0,0273 & 0,3856 & 0,2355 & $-0,0054$ & 1 \\
\hline
\end{tabular}


According to the correlation matrix, infant mortality correlates negatively with the population employed in health and social assistance, with employees and with persons with higher education, therefore it is higher where they have low values. The strong correlation of the employed population and the employees with the higher studies shows that these factors constitute a favorable context for the decrease of infant mortality, explaining types 1-2 of the AHC and the Roma population is positively correlated with high birth rates, unemployment and poor education, practically resulting in two distinct where the extremes are Iași and Lungani (table 1). It certifies the results of the descriptive statistical analysis and the field surveys carried out.

\section{CONCLUSIONS}

From the point of view of the reference indicator, our country has gone a specific road to countries in transition, characterized by a significant reduction in child mortality.

The main contribution of this article is to analyze local events and trends, which are necessary following the analysis of general trends, at national and county level. It is partially confirmed that the high values of the indicator analyzed can be associated in some counties/communes with the existence of important Roma communities. The confessional component has much less influence on child mortality than ethnic, with some principles or rules of religion directly influencing the family's standard of living, the number of members per family or the level of morality, to be open to the West or to deny modernity and to promote traditional principles. The peri-urban areas of large cities have significantly improved the impact of this indicator, in contrast to isolated municipalities that are disadvantaged in terms of access to health infrastructure, where high values are maintained. The results of the study show obvious limitations, generated by the sometimes incomplete information, the general nature of analyzed parameters or the subjectivity of local administrative bodies.

According to the Save The Children Foundation, the main cause of child mortality in our country is premature births; one third of these could be prevented by developing support programs for mothers and children and by the development and modernization of maternity and newborn sections, therefore the development of economic policies, Health and education and investment in these fields seems to be essential at local level in Iași county.

Acknowledgement: This work was co-funded by the European Social Fund, through Operational Programme Human Capital 2014-2020, project number POCU/380/6/13/123623, project title "PhD Students and Postdoctoral Researchers Prepared for the Labour Market!".

\section{REFERENCES}

Bardet, J.-P., Dupâquier, J. (1999). Histoire des populations de l'Europe, Fayard, vol. III, Paris.

Burlea, A.M. (2012). Multilevel analysis of infant mortality in Romania. Revista de Cercetare şi Intervenţie Socială, (39), $100-116$.

Dumitrache, L. (2004). Starea de sănătate a populației României: o abordare geografică, [The Romanian population health status-a geographic approach], Editura Univers Enciclopedic, București.

Istrate, M. (2008). Relaţiile urban-rural în Moldova în perioada contemporană, Edit. Universităţii "Alexandru Ioan Cuza", Iaşi, 352.

Jemna, D. V. (2015). Causality relationship between economic development and fertility in Romania on regional level. Procedia Economics and Finance, 20, 334-341.

Kurkó, I. (2010). Disparităţi geodemografice şi economice din România în perioada de tranziţie. Presa Universitară Clujeană.

Onambele, L., San Martin-Rodríguez, L., Niu, H., Alvarez-Alvarez, I., Arnedo-Pena, A., Guillen-Grima, F., \& AguinagaOntoso, I. (2019). Mortalidad infantil en la Unión Europea: análisis de tendencias en el período 1994-2015. In Anales de Pediatría, 91(4), 219-227. https://doi.org/10.1016/j.anpedi.2018.10.022

Pressat, R. (1974). Analiza demografică (Demographic analysis). Editura Ştiinţifică, Bucureşti.

Reidpath, D. D., \& Allotey, P. (2003). Infant mortality rate as an indicator of population health. Journal of Epidemiology \& Community Health, 57(5), 344-346. https://jech.bmj.com/content/57/5/344.

Rotariu, T. (2009). Demografie si sociologia populației. Structuri și procese demografice, Polirom, Iași.

Storeygard, A., Balk, D., Levy, M., \& Deane, G. (2008). The global distribution of infant mortality: A subnational Spatial view. Population, space and place, 14(3), 209-229. 
Trebici, V. (1975). Mică enciclopedie de demografie, Editura Științifică și Enciclopedică, București.

Tudora, D., \& Muntele, I. (2012). Coeziune teritorială şi disparităţi în Moldova, Ed. Universităţii „,Al. I. Cuza” Iaşi.

Corsini, C. A., \& VIAZZO, P. (1993). The decline of infant mortality in Europe, 1800-1950: four national case studies (pp. 1-86). UNICEF International Child Development Centre.

Waldhoer, T., Wald, M., \& Heinzl, H. (2008). Analysis of the spatial distribution of infant mortality by cause of death in Austria in 1984 to 2006. International Journal of Health Geographics, 7(1), 1-9.

*** World Population Data Sheet, 1995-2019 series, Population Reference Bureau, Washington, accesed at may 2020.

Submitted:

March 21, 2020
Revised:

June 12, 2019
Accepted and published online

July 15,2020 